\title{
LANDSCAPES OF MEANING: views from within the Indian Archipelago
}

\section{Transforming Cultures eJ ournal, \\ Vol. 3 No 1, February 2008 \\ http:// epress.lib.uts.edu.au/journals/TfC}

\section{Heather Goodall}

In 1848, Thomas Mitchell, the influential Surveyor General of NSW, depicted Australia as lying embedded within 'the Indian Archipelago'.

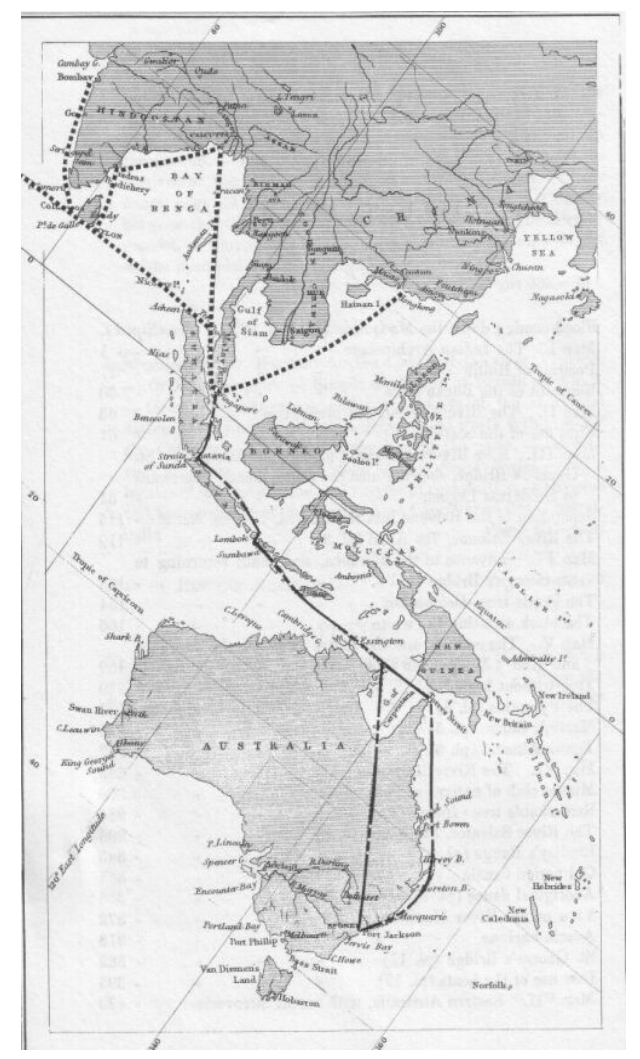

The map he drew looked from Sydney through to the north west, making Australia just one of the chain of islands stretching north west through the East Indies, along the coasts of Malaya and Burma and on to India itself.

Like all surveyors, Mitchell understood that to map a landscape, one first of all had to have imagined what it means - and this involved imagining its future as well as its geography. He was demonstrating to an Australian audience that their future lay within the region, in networks of trade and culture with the rich societies to its north and west across the Indian Ocean.

The imagined landscape for most later Australians was very different. For the rest of the $19^{\text {th }}$ and $20^{\text {th }}$ centuries, Australians saw themselves as living on an isolated, lonely island, surrounded by tempestuous seas and coveted, from a distance, by peoples alien

\footnotetext{
${ }^{1}$ Thomas Mitchell: Journal of an Expedition into the Interior of Tropical Australia in search of a Route from Sydney to the Gulf of Carpentaria, first published in 1848, Chapter 1, Map 1: 'The Indian Archipelago' currently available by Gutenberg Press at <http://www.gutenberg.org/files/9943/9943h/9943-h.htm> Dr Haripriya Rangan drew my attention to this image. See her forthcoming publication with Christian Kull 'The Indian Ocean and the Making of Outback Australia: an ecocultural odyssey' in Ashraf Jamal and Shanti Moorthy (eds.) Black Water: Indian Ocean World, University of Malaysia and Cambridge University Press (forthcoming) 2008
} 
to it in race and cultures. Australia's only links were portrayed to be with far-off Britain and northern America, held by fragile threads of contact spun out across miles of uncertain ocean, sustained only by the precarious routes of sailboats and steamships. The oceans themselves were seen as empty and threatening, in contrast to the landbased empires, colonies and nations which were endlessly studied and worried over.

Indian Ocean meanings do not have to be so limited. Thomas Metcalf has published the most recent of the important histories of the Indian Ocean. In his Imperial Connections: India in the Indian Ocean arena, $1860-1920^{2}$ he has returned to the meaning of seas as rich interwoven pathways, storied and enlivened by generations of voyages, which were only increased, not surplanted, in meaning with the expansion of crossings in colonial times. Metcalf tracks the destinations and then the complex histories of the large Indian diasporic populations which developed around the coast of Africa, the middle East and mainland south east Asia, both before and after European colonisation. At the same time he explores the ways in which Indian culture, economies and conditions shaped the development by the British of its 'colonial code', its structures for indirect and direct rule over 'uncivilised' colonized populations, however cultured and ancient their societies might be. After the British shaped such models for governance inside India, these same structures of law, administration and engineering were exported to other colonies of the empire as if they were British 'inventions', their underlying Indian influences seldom recorded or acknowledged. ${ }^{3}$

Metcalf focuses attention onto the key role of India and Indians in the Indian Ocean region right up until decolonization. But the questions Metcalf pursues lead to a significant gap in his imagining of the Indian Ocean. The whole south eastern quadrant with the Dutch colonies of the Netherlands East Indies and the continent of Australia, are missing entirely from Imperial Connections. They don't fit Metcalf's focus of interest because either they don't have a substantial Indian diasporic community or the British colonial codes appear not to have been implemented there.

Yet these places do form a major part of the ocean world and each has been strongly influenced by India in the distant or the recent past. Just as important, their ports, coasts and cities still offer launching or anchoring points for connections which continue to be

\footnotetext{
${ }^{2}$ UCLA Press, 2007

${ }^{3}$ Metcalf, 2007, Imperial Connections ‘Introduction', 1-15, and passim
} 
woven across the Indian Ocean today. The pre-colonial crossings from mainland South, South East and East Asia through the Indonesian Archipelago to Indigenous Australia are well documented if not well studied, and the influences on language and ecologies are just being opened up. Barriers of language and politics operated between the Dutch and Portuguese colonies of the East Indies and the British colonies of Malaya and Australia. So too did ideological barriers which bound the 'settlers', both Dutch and British, in South Africa and Australia who saw themselves as 'civilized' when they compared themselves to the indirectly or directly ruled non-European subjects in the colonies of the Indies, south-east Asia and South Asia. These barriers all acted to obstruct the flow of communication and recognition across the Indian Ocean and they have persisted perhaps even more strongly after decolonization, when the dissolution of global imperial links has left nation states concentrating on forming more narrow nation-to-nation alliances.

Yet the communication and the movement of people, ideas, plants and animals continued throughout colonial rule even though it was seldom acknowledged. It was, in fact, often illicit. Now, the dramatic shifts in today's global economies and communications have breached these divisions. Indian scholars, scientists, technology experts and environmental activists, along with Indian films, singers and cricketers are all now in high profile in the Australian consciousness. Indonesian finance is penetrating the farming lands of West Bengal, Australia seeks to sell its uranium to India and Australian media moguls continue to intervene in the world cricket industry, even as Indian capital and fans change the future of the game. Thomas Metcalf's important work signals the return of attention to the key role of India. At the same time, the gaps in his imagined landscape point to the urgent need to reopen pathways to learn how the south eastern quadrant of the Indian Ocean has been and will in the future be linked to the rest of the region: back, indeed, into the Indian Archipelago which Mitchell could see in 1848.

The Landscapes of Meaning symposium held in October 2006 was an early step in that process of opening the conversation between India and Australia. The two focal themes were Rethinking Diasporas and Environment and Social Justice. Overall, the symposium was framed by Dr Haripriya Rangan (Geography, Monash University) who 
discussed her own research in political ecology ${ }^{4}$ to demonstrate the potential of strongly theorized comparative work across the Indian Ocean to offer insights into the ecological and social histories of India, Australia and southern Africa which are not available if one remains confined to national borders as the unit of analysis.

During the conference, four established Indian researchers worked with Australian researchers and students from a number of Universities in Sydney, Melbourne and Canberra. In the environmental session, key community and Indigenous advocates and agency and NGO staff met with these academic researchers. Some of the Australians present were themselves from an Indian background while others were from Indian diasporic communities. Some were teaching in areas in South Asian Studies, others in World History and some in Australian environmental studies. But the symposium went further than regional studies. It allowed the opening of new research directions into the intercolonial interaction of Australian and Indian histories to assess the contemporary links between the two areas.

Just as valuable, the symposium offered a rare forum independent of the usual government consultative structures for conversation between Indigenous and community environmental activists, NGO staff, government agency staff and academic researchers from Australia and India. This discussion is reflected in the structure of this volume. The first two sections, on the themes of the conference, contain refereed articles which reflect ongoing research but also indicate several new research directions from established and emerging scholars.

The third section, Conversations, is centred on three interviews with key participants in the Environment and Social Justice session: a community environmental advocate, an Aboriginal community spokesperson and an activist in one of the few major nongovernment environmental organizations, whose views are seldom seen in conventional academic form. They discuss the experiences and challenges in their roles in the fostering of shared decision-making between Indigenous communities, environmental

\footnotetext{
${ }^{4}$ Rangan, H. 'From Chipko to Uttaranchal: The Environment of Protest and Development in the Indian Himalaya', in R. Peet and M. Watts eds. Liberation Ecologies, Second Edition, 2004; Rangan, H. and Gilmartin, M. 'Gender, Traditional Authority, and the Politics of Rural Reform in South Africa', 2002, Development and Change, 33 (4): 633-658; Rangan, H. 'The Muti Trade: South Africa's Indigenous Medicines', Diversity, 2001, 2 (6): 16-25; Rangan, H. Of Myths and Movements: Rewriting Chipko into Himalayan History, 2001 Oxford University Press. Delhi.
} 
NGOs, scientists and government agencies. Their reflective interviews are, in two cases, followed by comments which accompany them from fellow participants or environmentalists, in Australia and in India. The interviews and comments together cover a range of questions seldom explored and even less often opened up for further discussion.

The first section of this journal issue is based on the symposium theme Rethinking Diasporas. The essays investigate the often unrecognized movements of people between South Asia and Australia and the questions around the constructions of identity in the contexts of migrancy in colonial and post-colonial settings. Led by established Indian scholars Professor Anjali Roy (IIT Kharagpur) and Professor Lakshmi Subramaniam (Jamia Milia Islamia University), this session explored the changing nature of diasporic communities of South Asians, often characterized as homogenously 'Indian'. Anjali Roy, in her paper here, demonstrates the complex and changing selfrepresentations of three large but very different diasporic groups in Australia: Sikhs, Anglo-Indians and 'IIT-ans', the latter being members of the professional elite groups who have been employed and often settle in the US, Canada or Australia. She argues that each group has constructed their identities differently over time, reflecting the dramatically changing events and polarizations in India including Partition [affecting the Anglo-Indians] and the 1984 storming of the Golden Temple [affecting Sikhs], while IIT-ans shape their identity around an institution rather than the national identity with which they are labeled in host societies like Australia.

Lakshmi Subramaniam and Urmila Goel, (both this volume) while analyzing very different Indian diasporic communities in the United States and in Germany respectively, share a common conclusion that the context of the host country and its own social tensions were key factors in shaping the way the diasporic community members both expressed and represented themselves as Indians. Deborah Nixon's essay (this volume) points to the contradictions between memory and photographic records as she explores her father's recollections of his life as a domiciled Anglo-Indian. She suggests that memory has recomposed - and erased - not only the troubling intercommunity marriages which became an embarrassment for later generations but also the horrors of witnessing the intense trauma of Partition. Heather Goodall, Devleena Ghosh 
and Lindi Todd (this volume) explore similar questions of memory and politics but do so from the Australian side. Significant numbers of Indians have lived in Australia among communities like those of Aboriginal people and in interaction with maritime workers. In both these Australian communities memory and popular culture has kept the stories alive in which Indians emerge not only as individuals with complex personal and working histories, but often as activists in the campaigns against racism and in support of decolonization. Yet this Indian heritage has been obscured by the same pressures: Aboriginal people, for example, have often been forced to chose a simple identity, as either 'black' or 'white'. The harsh polarizing racial politics of settler Australia has had no sympathy for complicated ancestries so Indian backgrounds have seldom been explored or celebrated.

Taking up the theme of popular culture opened by Subramaniam and Goel, Jann Dark and Manisha Amin (both this volume) deal with representations of cultural crossings relating to India. Dark considers the positioning of white women in two prominent films, Lagaan and Rang de Basanti, by Indian directors. In an experimental literary form, Manisha Amin explores the narratives told within in her twice-migrated family in their accounts of lives lived shifting between homes in the Punjab, Kenya, London, Bangalore and Australia.

The second theme, Environment and Social Justice, focused on the emerging field of environmental politics \& history. In this area, there have been less obvious movements between South Asia and Australia although these have occurred, as discussed by Haripriya Rangan and Christian Kull on pre-colonial acacias ${ }^{5}$ and Jodi Frawley on colonial mangoes (this volume). Today the rising impact of global markets, international tourism and NGO environmental activism has escalated present day interactions, in both directions. They are often seen to be facing similar environmental crises, characterized in Australia as the human impact on 'wilderness' and which in India have been reflected in related to international tourism and ill-informed international environmentalism. Symposium key speaker Professor Ranjan Chakrabarti (History, Jadavpur University) discussed this question in relation to the coastal

\footnotetext{
${ }^{5}$ Haripriya Rangan and Christian Kull 'The Indian Ocean and the Making of Outback Australia', op.cit., forthcoming 2008
} 
mangrove lands of the Sunderbans in West Bengal ${ }^{6}$, while Jeff Neilsen (this volume) drew on his research into production in the coffee forests of Kodagu in Southern India to reflect on the same issues around international markets for plantation crops. International interventions have been problematic in each case, whether they involved commercial extraction or tourism for profit or liberal social movement NGOs hoping to achieve more effective conservation or 'fair trade' coffee. Like many others in South Asia, both the situations discussed at the symposium have in fact had not one or the other, but a combination of both.

This theme of environmental politics and history is inevitably engaged, in both Australia and India, with questions around social justice. The environmental sessions were framed at the symposium by Professor Mahesh Rangarajan (Delhi University) and by Jacqui Katona, spokesperson for her community who are the traditional owners of the highly contested Ranger and Jabiluka uranium mines within Kakadu National Park.

Mahesh Rangarajan discussed the tensions in attempts to solve urgent environmental crises in protected areas in India, where too often the protection of iconic mammals and forest environments has proceeded by displacement of indigenous and local communities. ${ }^{7}$ Such communities are blamed for what are in fact the impacts of the wider shifts in regional economies which arise as globalised development proceeds. Displaced on little or no evidence of real benefit to environmental outcomes, such communities are left unhappily marginalized and impoverished in ill-chosen sites or 'buffer zones’ with little regard for their economic or cultural survival.

There have however been important developments in which social scientists and ecological scientists have worked together to strengthen research into the causes of biodiversity loss and into the effectiveness of innovative strategies which protect local and indigenous communities but also deliver conservation benefits. These developments, introduced by Mahesh Rangarajan and Ghazala Shahabuddin in their recent Making Conservation Work (Permanent Black, 2007 which is reviewed by Denis Byrne, this volume) offered lessons for Australians grappling with similar problems.

\footnotetext{
${ }^{6}$ A number of the authors address these issues in Ranjan Chakrabarti's 2006 edited volume: Does Environmental History Matter? Tandrita Chandra (Bhaduri), Kolkata.

7 See Mahesh Rangarajan, 'The Problem' in Seminar 577, September 2007, Nature, Wildlife \& People: wildlife protection \& people's livelihoods, <http://www.india-seminar.com/2007/577/577_the_problem.htm>
} 
The usefulness of this comparison was debated in the symposium and many of the essays, and particularly the opinions and interviews in the Conversations section, offer Australian responses and Indian perspectives in these ongoing debates.

Jacqui Katona described the interactions between the struggling but eventually successful Mirrar Traditional Owners at Kakadu and their troubled alliance with national and international environmental lobby groups as they all tried to stop new uranium mining. Jacqui described an eventful relationship, in which environmental groups had been forced to negotiate and reshape their demands as increasingly more meaningful dialogues with the local Aboriginal community developed over the course of several campaigns. The result was a better informed and ultimately more effective alliance which, although not without its tensions, nevertheless led to substantial gains in both conservation goals and in community empowerment. ${ }^{8}$

The relations between Indigenous peoples and conservation debates are explored in the first two papers in this section. Fiona Paisley develops her new research into the international activism of Anthony Martin Fernando, an Indigenous Australian who spoke out in Europe the 1920s demanding justice for his people. Fernando's mother came from the local Aboriginal communities near Sydney, but his father appears to have been an Indian seafarer, one of the many 'lascars' who passed through Sydney ports and, as Goodall, Ghosh and Todd have demonstrated, became involved with Aboriginal communities. Fernando's unprecedented statements in the Swiss media in 1921 were received by Europeans in the context of their rising perception that both remote environments and indigenous colonized cultures were in danger. Fernando would not have chosen this framing and continued to be frustrated by the misunderstandings with which his demands were met. Kerry Little is researching the narratives of tradition and the sacred in Sikkim, where the Lepcha with whom she is working are grappling with rapid change in many forms, but are particularly challenged by the planned construction on their rivers of six dams to produce hydro-electric power, which threaten to flood areas they hold to be sacred. Little is now documenting not only the stories themselves but the mobilization of large cross-sections of the Lepcha population around the traditions recounted in these stories as they try to defend the sites.

\footnotetext{
${ }^{8}$ Jacqui Katona has published a review of the issues for Mirrar people in Kakadu in her recent 'The Mirrar fight for Jabiluka: Uranium mining and Indigenous Australians to 2004' in S. Washington-Hood, P. Rosier and H. Goodall (eds.) Echoes from the Poisoned Well: Global Memories of Environmental Injustice, Lexington Books, (Lanham, MD, 2006) pp 285-298.
} 
The conflict in Sikkim reflects a common focus of conflict in Australia, that of Indigenous interests in land, which simultaneously include cultural, livelihood and conservation dimensions. Haripriya Rangan's comparative work on forestry in India and Australia has pointed to the prioritizing of one or the other in both Indian and Australian administrations. The focus on 'culture' in Australia has often led to agreements which have excluded Aboriginal interests in land as a productive site, at the same time as they seek protection for its cultural significance. ${ }^{9}$ Sue Feary's paper (this volume) addresses this question, as she investigates Australian situations in which, contrary to environmental NGO expectations, local Indigenous communities with long histories of interacting with forestry have supported contemporary forestry. Her paper is discussed in the Conversations section by Heidi Norman, a researcher in land politics whose Gamilaraay family is part of just such a community. Feary goes on to analyse the agreements in three forestry concerns in which Indigenous communities have negotiated their participation only on conditions which allow them to express their cultural interests at the same time as they are recognized as beneficiaries of the industry's economic outcome. The interacting nature of 'culture' and 'economy' in Indigenous relationships is the focus of Denis Byrne's influential work in 'counter mapping' (this volume) in which he has traced the possibilities of making visible the very different Indigenous patterns of movement and use of land in today's highly populated Australian coastal environments, not only in sparsely settled 'remote' areas or in some mythical past. His account allows an insight into Aboriginal people's sustained interaction with land in both cultural and economic dimensions despite the appearance of complete domination by Anglo-Australian settlers.

This section closes with an important paper by Dr Michael Adams, which brings together his extensive comparative research into the complex interactions between Indigenous and non-Indigenous groups in conservation management in Australia (in both government and non-government controlled settings in a number of state jurisdictions) and more recently among the Sami and the States in the Artic circle of northern Europe. Starting from the premise of the clear policy failure in areas of joint management at State and Federal levels, Adams looks for its causes but also its

\footnotetext{
${ }^{9}$ Rangan, Haripriya, and Marcus B. Lane. "'Indigenous Peoples and Forest Management: Comparative Analysis of Institutional Approaches in Australia and India'." Society and Natural Resources 14, no. 2 (2001): 145-60.
} 
opportunities. Adams discusses the pervasive effects of the perception of the irreconcilable opposition of 'foundational myths'. These include 'wilderness' which despite critiques continues to win great emotional commitment from Anglo Australians as well as from other post-colonial settler societies. These mythic beliefs also include 'homelands', with its equally powerful but poorly understood messages for Indigenous Australians. Whatever their relation to past and present realities, such mythic constructions hold enormous evocative power over communities and conservation professionals alike. Adams argues for innovative approaches in on-the-ground negotiations which recognize complementarity in cultural approaches rather than seeking the dominance of one side or the other. He identifies the formation of 'recognition spaces': physical and legislative areas where such cross-cultural negotiations might develop. 'Joint management' arrangements of protected lands offer one such space - not as solutions in themselves but as spaces in which there is a motivation to work towards new collaborative solutions. Adams then proceeds to look critically how far this potential for cross-cultural collaboration has developed in three types of jointly managed tenure over protected areas in Australia and discusses the outcomes for biodiversity conservation and for social justice.

The third section, Conversations, then takes up many of these themes in relation to the experiences of three key activists who spoke at the symposium: Peter Thompson, community-based environmental activist from Coonabarabran and long time advocate for Darling River Indigenous communities; Yvonne Stewart, Bandjalang woman from Byron Bay and spokesperson for the Arakwal Elders Group and Anthony Esposito, activist with The Wilderness Society (TWS) and Director of their Indigenous engagement program, as part of TWS's Wild Country program developing broad regionally-focused conservation strategies. Coming from my own research background on Indigenous land politics and on environmental history, I interviewed them individually early in 2007, asking them to expand on how the issues and tensions discussed at the symposium had been visible in their own work. Each of them brings important new insights into the challenges and breakthroughs which have been made in joint management negotiations and practice - on the ground.

Peter Thompson discusses the campaign for Mutawintji, the first jointly managed national park in NSW, then the frustrating negotiations between the local Indigenous 
communities and the National Parks bureaucracy to implement the flawed agreement, since renamed 'Co-Management'. Hopes are emerging for a more equitable renegotiation of the agreement over these parklands. However the lessons learned by the broader Aboriginal community and their advisers, like Peter, from the Mutawintji experience have led to a different approach being taken by the communities negotiating for Gamilaraay interests in the newly declared Brigalow and Nandewar Community Conservation Area in central western NSW, the area in which Heidi Norman's family have an interest. In this area, encompassing the old Aboriginal community site at Terry Hie Hie, the State Government has explicitly ruled out any form of future 'joint management'. Yet the Aboriginal communities in the area have just as active an interest in their land, for both traditional and historical reasons, as those further west do at Mutawintji. So the Gamilaraay are pursuing different strategies to achieve, eventually, a place at the management table. Michael Adams in his commentary reflects on the issues raised by Peter Thompson's analysis of the Mutawintji and Brigalow and Nandewar experiences as people have tried to make shared management really work.

Yvonne Stewart in her interview explains the negotiations by the Bandjalang community of Byron Bay on the north coast NSW in their campaign to achieve Native Title. This form of tenure means recognition of some rights over traditional lands, although not freehold title or 'ownership'. At Byron Bay, the community has chosen to exercise their Native Title by developing what they decided to call Joint Management with National Parks. This has been a complex task which challenges the community here, as it did at Mutawintji, in the shift from campaigning for land to managing it, with all the constraints of another set of imperfect legislative tools and ambivalent bureaucratic partners. Like Mutawintji too, this community organization has had to search before finding scientific advisers who gave them the environmental knowledge about restoration which they were seeking but who also recognized the cultural imperatives under which the community wanted to manage the land. The Arakwal community was however presented with a sudden new option, a marine national park. They used the opening this unexpected event offered to extend the education and livelihood potential of their agreements beyond the land they jointly manage.

Finally, Anthony Esposito discusses how a major conservation NGO, The Wilderness Society (TWS) has faced the challenges which Aboriginal people have posed in 
demanding a role in conservation management. The result has been an innovative attempt to engage their 'Wild Country' project, which TWS had earlier adapted from an existing program in the USA, with the rising degree of collaboration with Aboriginal communities which TWS activists like Esposito had begun to achieve in Queensland and Northern Australia in organizing around particular local campaigns. This very real effort by a large and powerful NGO to negotiate with Aboriginal people as conservation partners, rather than to position them as just another threat to 'wilderness', is a major innovation in Australia's civil society environmental advocacy. The complexities of its implementation, the areas of its greatest strengths as well as the limitations and continuing unresolved tensions of this NGO initiative are considered in Esposito's reflective interview.

This Conversations section concludes by returning to the question which underlay the whole Landscapes of Meaning symposium: are there useful comparisons which can be drawn between Australian and South Asian experiences and problems? Dr Ghazala Shahabuddin, a biologist, environmental researcher and co-editor of Making Conservation Work (reviewed this volume) considers here Anthony Esposito's account of the Wilderness Society approach and the conditions from which it emerged. She argues that there are valuable insights to be learned from both Indian and Australian protection approaches but she points out the important differences as well, particularly in the scale of the programs, the goals of all parties and the role of government in the three cornered relationship between the state, NGOs and local and Indigenous communities. In focusing on the key dilemma of the tensions between conservation and social justice goals, Ghazala Shahabuddin points out that it remains an unresolved question, for both Indian and Australian advocates, whether any one program can fulfill both those goals. Her discussion identifies a series of important questions which would be valuable to pursue to assess how effective the Wild Country program was in practice. One of the areas she notes with interest, however, is the wide range of types of landscapes which are considered in these Wild Country regional approaches, which are based on the broadest assessment of the way all types of country in a region contribute to biodiversity conservation, not just the patches within protected area boundaries. This allows an opening for negotiation which she argues might resolve some of the conflicts across the traditional divide between social activists and biologists of which she has been aware in India. Looking forward to approaches for both Australia and India, 
Ghazala Shahabuddin sees a situation not dissimilar to Michael Adams in his sketch of 'recognition spaces' when she suggests that a consideration of the broader mosaic of a region in biodiversity terms rather than a narrow focus on protected areas alone may offer at least a meeting ground from which more effective discussions can begin.

This volume closes with a new Book Reviews section, in which authors of a number of the refereed articles have chosen books to discuss which grapple with the themes of this issue: rethinking diasporic identity and settler colonialism, debating conservation and social justice. Each of these books explores with the ways in which landscapes and nature are constructed in the social and cultural conflicts over colonialism and its aftermaths. All problematise the simplistic cultural dichotomies that colonial conflicts imposed and in doing so they bring new multi-ethnic and fruitful approaches. Particularly Coombes' edited Rethinking Settler Colonialism [reviewed here by Lindi Todd] and Rangarajan and Shahabuddin's edited Making Conservation Work [reviewed here by Denis Byrne] have direct relevance to emerging and urgent debates in Australia and India. They remind us that imagining landscapes, just as it was for Thomas Mitchell in 1848, is today still a challenging intervention into public politics. 